\title{
Metode Daring Dalam Meningkatkan Efektivitas Penyuluhan Pada Masa New Normal
}

\author{
Ramon Syahrial ${ }^{1}$, Adi budiwan.SP.,M.A.gr ${ }^{2}$, Heri Susanto, SP., MM $^{3}$ \\ Fakultas Pertanian, Agribisnis, Universitas Wijaya Putra
}

ramonsyahrial@uwp.ac.id, adibudiwan@uwp.ac.id, $\underline{\text { herisusanto@uwp.ac.id }}$

\begin{abstract}
Abstrak
Penyuluh berada di garis terdepan dalam upaya Kementan mewujudkan pertanian yang mandiri, moderen dan maju. Gapoktan yang terletak di Desa Mondoluku, Kecamatan Wringinanom, Kabupaten Gresik, Jawa Timur. Desa Mondoluku mempunyai 16 Gapoktan dan 46 poktan yang dibina oleh Kecamatan Wringinanom. Dengan jumlah gapoktan dan poktan tersebut muncul permasalahan yang dialami para penyuluh, kendala tersebut berkaitan dengan jarak antara poktan dan waktu yang sangat susah dapat ditentukan karena pekerjaan sebagai petani dan keperluan lainnya ditambah dengan kondisi wabah covid-19 dengan protokol kesehatan yang ketat.

Berdasarkan prioritas permasalahan seperti tersebut diatas, tim pengabdian kepada masyarakat memberikan wawasan tentang teknologi komunikasi yang ada pada smartphone dan memberikan pelatihan berkaitan dengan penggunaan teknologi komunikasi disesuaikan dengan kepentingan dan kebutuhannya dalam proses penyuluhan. Dengan segala keterbatasan, penyuluh wajib berinovasi dengan teknologi informasi yang ada dan mudah diakses oleh masyarakat petani. Aplikasi Whatsapp Grup (WAG) dan Google Meet jadi pilihan karena simple dan bisa dijadikan sebagai media komunikasi dalam menginformasikan penyuluh dan gapoktan dengan segala bentuk informasi baik antara penyuluh dan gapoktan atau antara gapoktan dan poktan.
\end{abstract}

Kata kunci: metode daring, peran penyuluh, efektifitas penyuluhan

\section{PENDAHULUAN}

Pandemi Covid-19 mempengaruhi semua orang di dunia tanpa terkecuali, tetapi dengan efek yang berbeda antar manusia. tidak hanya pada sektor kesehatan, tetapi juga sosial ekonomi masyarakat. Dari sisi protokol kesehatan, pemerintah sudah menyiapkan strategi khusus untuk mencegah penyebaran virus melalui pembatasan sosial berskala besar (PSBB). Strategi itu hanya akan efektif sepanjang pangan pokok tersedia untuk rakyat.

Kehadiran Penyuluh Lapangan Pertanian (PPL) dan peran pendampingan pertanian di tengah masyarakat pedesaan masih sangat dibutuhkan untuk meningkatkan sumber daya manusia (petani) agar dapat secara intensif meningkatkan sumber daya alam yang tersedia. meningkatkan produktivitas dan pendapatan atau mencapai ketahanan dan ketahanan pangan.

Pandemi covid-19 tidak boleh menjadi penghalang penyuluh untuk terus mendampingi petani. Kementan sudah memiliki wadah Kostratani yang dilengkapi teknologi informasi digital sehingga pendampingan bisa dilakukan kapan pun dan di mana pun. Langkah berikutnya yang juga berperan penting ialah optimalisasi lahan. optimalisasi seluruh lahan pertanian di Indonesia perlu gerakan antarlintas sektoral. Di tengah kebijakan pemerintah terkait penerapan new normal di berbagai wilayah di Indonesia, penyuluh pertanian memiliki peran strategis dalam rangka memberikan respon terhadap para petani yang terdampak Covid-19, terutama para petani yang berada di daerah pedesaan.

Peran penyuluhan dimasa pandemi Covid-19 ini bukan hanya sekedar menghubungkan petani dengan pemerintah. Penyuluh pertanian juga harus membantu petani di pedesaan untuk

Teknologi Informasi dan Komunikasi | 46 
mengatasi masalah baru yang tidak dapat ditemukan solusinya oleh mereka sendiri, oleh karena itu penyuluh pertanian hadir untuk petani, Keterbatasan fisik dalam rangka melaksanakan anjuran pemerintah melakukan Phsycal distancing mendorong seorang penyuluh untuk berinovasi memanfaatkan teknologi informasi yang sederhana, tersedia dan mudah diakses oleh masyarakat pedesaan seperti memanfaatkan smartphone dan media sosial sebagai media penyuluhan alternatif.

Selain pesatnya perkembangan teknologi informasi dan komunikasi, program pendampingan harus selalu memanfaatkan perkembangan teknologi tersebut untuk menjangkau petani milenial. Namun, sasarannya adalah para petani muda yang sudah aktif menggunakan Android untuk kebutuhan komunikasi dan informasi melalui penggunaan internet. Adanya komunikasi tersebut ditandai dengan transfer teknologi yang terus menerus melalui proses uji coba yang dapat berujung pada peningkatan produksi pada usahatani yang dioperasikan oleh petani. Peran PPL adalah untuk menggambarkan proses penyampaian pengetahuan dan teknologi sumber daya kepada masyarakat pertanian yang membutuhkannya.

Keberadaan Gapoktan Di Kecamatan Wringinanom tak luput dari peran penyuluh pertanian (PPL) yang berada di BP3K (Balai Penyuluhan Pertanian, Perikanan, Dan Kehutanan) Kecamatan Wriginanom Kabupaten Gresik yang bertujuan meningkatkan pemberdayaan kelembagaan petani di wilayah Kecamatan Wringinanom. Salah satu faktor yang mempengaruhi tingkat perkembangan Gapoktan adalah terlaksananya peran penyuluh pertanian dengan baik.

Guna terlaksananya programprogram penyuluhan yang telah disusun dibutuhkan intensitas dalam komunikasi antara penyuluh (PPL) dan gapoktan, disatu sisi keterbatasan sarana prasarana, kurangnya pengetahuan teknologi dan penguasaannya, serta bagaimana mengaplikasikan teknologi komunikasi secara optimal khususnya yang tersedia pada alat komunikasi yang berbasis Android.

Berdasarkan penjelasan dan hasil diskusi dengan PPL, Gapoktan dan observasi lapangan yang dilakukan, masih ada beberapa permasalahan, antara lain:

1. Alat komunikasi modern (handphone) yang digunakan hanya untuk komunikasi pada umumnya dalam penggunaa

2. Masyarakat pertanian belum banyak yang mengerti dan memahami aplikasi dalam handphone sebagai sarana atau alat penyuluhan yang sangat efektif

3. Petani dituntut untuk mendapatkan informasiinformasi secara cepat dan harus bisa memilah-milah informasi yang didapatkan di era Pandemi Covid-19 ini.

\section{METODE}

Pengabdian kepada masyarakat dalam pelaksanaannya dibagi dalam 3 (tiga) tahapan kegiatan yaitu pada tahap pertama dilakukan dengan metode ceramah dalam memberikan materi, pada tahap kedua dilakukan dengan melakukan pelatihan dan pada tahap ketiga dilakukan pendampingan dengan berkunjung pada penyuluh (PPL) dan gapoktan berkaitan dengan sampai sejauh mana aplikasi dan penguasaan dalam menggunakan teknologi komunikasi yang tawarkan. Secara rinci tahapan dalam pelaksanaan pengabdian kepada masyarakat yang akan dilaksanaan adalah sebagai berikut:

1. Metode ceramah, dilakukan juga diskusi dan tanya jawab, hal ini diharapkan ada informasi atau keluhan dari peserta secara langsung sehingga diharapkan akan mudah untuk melanjutkan pada tahapan-tahapan selanjutnya.

Teknologi Informasi dan Komunikasi | 47 
2. Pelatihan, peserta akan melakukan pelatihan berkaitan dengan aplikasi teknologi komunikasi yang ditawarkan kepada penyuluh (PPL) dan gapoktan. Pada tahapan ini bertujuan untuk menilai sampai sejauh mana penyuluh dan gapoktan sebagai peserta memahami dan mampu menggunakan aplikasi yang ditawarkan.

3. Tahap pendampingan yang merupakan tahap akhir dari metode yang digunakan, tim pengabdian kepada masyarakat mengunjungi penyuluh (PPL) dan gapoktan guna mengetahui sampai sajauh mana dan kendala apa saja yang dapat ditemukan dalam menggunakan aplikasi teknologi komunikasi yang ditawarkan.

4. Tahap evaluasi, sebagai kelanjutan dari pendampingan dimana tim PPM menilai keefektifan dari aplikasi komunikasi yang sudah dipilih dengan segala kelebihan dan kelemahannya, serta kendala-kendala yang sering menjadi kendala dalam proses komunikasi, baik proses penyuluhan maupun komunikasi antara penyuluh (PPL) dan Gapoktan atau sebaliknya.

\begin{tabular}{|l|l|l|}
\hline Metode & Teknik & Target \\
\hline Ceramah & $\begin{array}{l}\text { Diskusi } \\
\text { dan Tanya } \\
\text { jawab }\end{array}$ & $\begin{array}{l}\text { Mengali } \\
\text { dan } \\
\text { mendapatk } \\
\text { an } \\
\text { informasi } \\
\text { dari } \\
\end{array}$ \\
& & peserta \\
& & sebagai \\
& & bahan \\
& & dalam \\
& & kegiatan \\
& & selanjutny \\
& & a \\
\hline Pelatihan & - Pertama & - Memperken \\
& sosialisa & alkan \\
& si dan & beberapa \\
& mengena & aplikasi \\
& lkan & teknologi \\
& beberapa & komunikasi \\
& aplikasi & yang ada \\
\hline
\end{tabular}

\begin{tabular}{|c|c|c|}
\hline & $\begin{array}{l}\text { teknolog } \\
\text { i } \\
\text { komunik } \\
\text { asi yang } \\
\text { ada pada } \\
\text { smartph } \\
\text { one. } \\
\text { - Kedua } \\
\text { melaksa } \\
\text { nakan } \\
\text { pelatihan } \\
\text { dari } \\
\text { aplikasi } \\
\text { yang } \\
\text { telah } \\
\text { disepaka } \\
\text { ti } \\
\text { digunaka } \\
\text { n dalam } \\
\text { proses } \\
\text { penyulu } \\
\text { han dan } \\
\text { komunik } \\
\text { asi }\end{array}$ & $\begin{array}{l}\text { pada } \\
\text { smartphone } \\
\text { beserta } \\
\text { kekurangan } \\
\text { dan } \\
\text { keunggulan } \\
\text { nya } \\
\text { - Aplikasi } \\
\text { yang telah } \\
\text { disepakati } \\
\text { sudah } \\
\text { dikuasai } \\
\text { untuk } \\
\text { digunakan } \\
\text { dalam } \\
\text { penyuluhan } \\
\text { dan } \\
\text { komunikasi } \\
\text { antara } \\
\text { penyuluh } \\
\text { (PPL) dan } \\
\text { gapoktan }\end{array}$ \\
\hline $\begin{array}{l}\text { Pendampi } \\
\text { ngan }\end{array}$ & $\begin{array}{l}\text { - Mendam } \\
\text { pingi } \\
\text { penyulu } \\
\text { h dalam } \\
\text { proses } \\
\text { penyulu } \\
\text { han. } \\
\text { - Mendam } \\
\text { pingi } \\
\text { gapoktan } \\
\text { dalam } \\
\text { proses } \\
\text { penyulu } \\
\text { han }\end{array}$ & $\begin{array}{l}\text { - Penyuluh } \\
\text { (PPL) } \\
\text { mampu } \\
\text { berkreasi } \\
\text { dalam } \\
\text { menggunak } \\
\text { an aplikasi } \\
\text { teknologi } \\
\text { komunikasi } \\
\text { yang } \\
\text { digunakan } \\
\text { serta } \\
\text { mampu dan } \\
\text { lancar } \\
\text { dalam } \\
\text { proses } \\
\text { penyuluhan } \\
\text { yang } \\
\text { dilakukan } \\
\text { - Tim } \\
\text { gapoktan } \\
\text { sudah } \\
\text { mampu } \\
\text { melakukan } \\
\text { komunikasi } \\
\text { secara } \\
\text { lancar baik } \\
\text { pada saat } \\
\text { proses } \\
\text { penyuluhan }\end{array}$ \\
\hline
\end{tabular}

Teknologi Informasi dan Komunikasi | 48 


\begin{tabular}{|l|l|l|}
\hline & & $\begin{array}{l}\text { maupun } \\
\text { pada saat } \\
\text { komunikasi. }\end{array}$ \\
\hline Evaluasi & - Melaksa & - Melakukan \\
& nakan & evaluasi \\
Evaluasi & dari \\
& dari & keefektifan \\
& pemakai & aplikasi \\
& an & yang telah \\
& aplikasi & dipakai dan \\
& & kendala apa \\
& & saja yang \\
& & sering \\
& & dirasakan \\
& & dalam \\
& & penggunann \\
& & ya. \\
\hline
\end{tabular}

\section{HASIL DAN PEMBAHASAN}

Guna menambah pengetahuan dan keahlian pada permasalahan pertanian/usaha tani serta berkaitan dengan usaha peningkatan Sumber Daya Manusia (SDM) di Desa Mondoluku, alternatif yang ditawarkan adalah dengan pendidikan non formal yaitu memberikan pelatihan dan kursus. Guna hal tersebut dibutuhkan peran serta penyuluh (PPL) dan gapoktan.

Keberadaan Gapoktan Di Kecamatan Wringinanom tak luput dari peran penyuluh (PPL) pertanian yang berada di BP3K (Balai Penyuluhan Pertanian, Perikanan, Dan Kehutanan) Kecamatan Wriginanom Kabupaten Gresik yang bertujuan meningkatkan pemberdayaan kelembagaan petani di wilayah Kecamatan Wringinanom. Salah satu faktor yang mempengaruhi tingkat perkembangan Gapoktan adalah terlaksananya peran penyuluh pertanian dengan baik.

Sesuai dengan proses pelaksanaan dalam program pemberdayaan masyarakat, ada beberapa tahapan yang dilakukan oleh tim untuk mencapai hasil yang diinginkan yaitu: 1). Tahap perencanaan, 2). Tahap pelaksanaan dan 3) Tahap Evaluasi

\section{Tahap Perencanaan}

Pada tahapan ini, tim program pemberdayaan masyarakat melaksanaka survey lokasi di mana mitra yang akan dituju. Selanjutnya sesuai dengan jadwal yang telah dsepakati guna berdiskusi dengan Kepala penyuluh, para penyuluh (PPL) dan tim gapoktan guna membahas rencana kegiatan yang akan dilaksanakan antata tim PPM, Penyuluh (PPL) dan Gapoktan di Desa Mondoluku, Kecamatan Weringinanom, Kabupaten Gresik. Diskusi berkaitan dengan rencana kegiatan yang akan dilaksanakan dilakukan agar kegiatan dapat dilaksanakan dengan baik.

\section{Tahap Pelaksanaan}

Tahap kedua dalam PPM ini adalah tahap pelaksanaan, sesuai dengan permasalahan yang mampu diabadikan oleh tim PPM kegiatan dibagi menjadi 3 kegiatan yaitu sosialisasi, pelatihan dan pendampingan. Penjabaran dari kegiatan yang dilaksanakan adalah sebagai berikut:

a. Sosialisasi

Sosialisasi dilaksanakan secara terbatas dengan mengundang 16 orang, setiap gapoktan diwakili oleh ketua dan 2 orang penyuluh dengan tetap memperhatikan protokol kesehatan. Kegiatan sosialisasi sesuai dengan kesepakatan dilaksanakan di rumah salah satu tim gapoktan. Pada sosialisasi ini, Tim PPM menyampaikan rencana kegiatan yang akan dilaksanakan. Inti dari sosialisasi ini adalah menawarkan kepada tim gapoktan dan tim penyuluh (PPL) untuk mendukung program pemerintah dalam mencegah penularan Covid-19 dengan tetap bisa menerima program-program penyuluhan Teknologi Informasi dan Komunikasi | 49 
dengan solusi yang ditawarkan dengan menggunakan aplikasi untuk komunikasi yang ada pada HP Android.

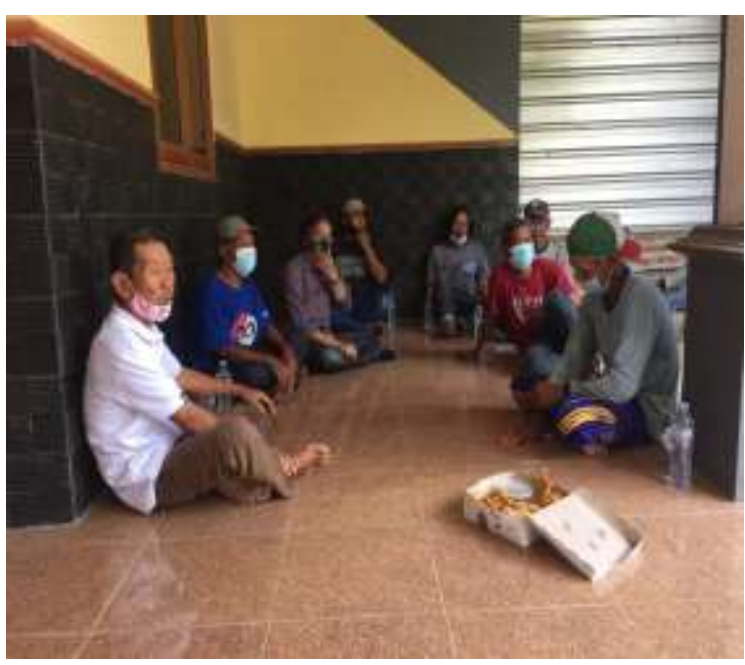

Gambar 1: Sosialisasi Aplikasi

b. Pelatihan

Pelatihan dilakukan dalam beberapa tahapan yaitu tahapan penyampaian materi dan tahapan praktek serta pendampingan. Dalam tahapan penyampaian materi dilakukan dengan cara ceramah dan diskusi atau tanya jawab bersama peserta, materi disampaikan dalam pemaparannya menggunakan media infocus.

Pelatihan dalam program pemberdayaan masyarakat yang dilaksanakan oleh tim terdiri dari:

a) Sebelum pelaksanaan pelatihan dan mengaplikasikan tentang alat komunikasi massa yang tersedia pada HP android tim PPM memberikan sosialisasi tentang berbagai macam teknologi komunikasi yang ada pada alat komunikasi (HP) khususnya yang berbasis android dengan segala kegunaannya, baik digunakan untuk komunikasi maupun digunakan untuk tranfers informasi, pengetahuan dan hal-hal teknis bagi penyuluh dan gapoktan tanpa terbatas waktu dan ruang.

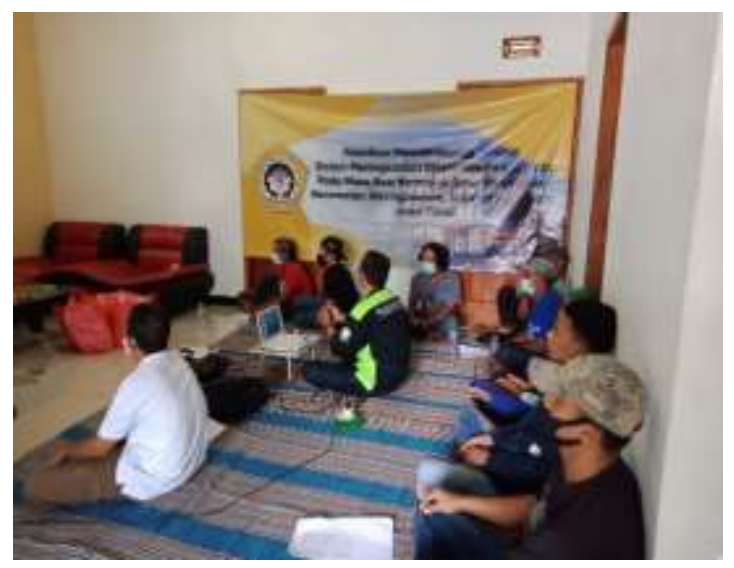

b) Pada jadwal selanjutnya setelah materi tentang aplikasi untuk komunikasi massa yang ada pada android telah dikenalkan dan dipahami keunggulannya dalam membantu proses penyampaian komunikasi bagi penyuluh dan gapoktan, ada 2 aplikasi yang diminati oleh para penyuluh dan gapoktan dalam pelaksanaan penyuluhan dan penyampaian informasi antara keduannya. Pemilihan aplikasi ini dengan mempertimbangkan yang pertama adalah biaya untuk data seluler mereka atau kuota, selanjutnya adalah keterjangkauan signal dimana mereka tinggal. Sehingga alternatif dari aplikasi yang kita tawarkan antara menggunakan zoom dan googlemeet guna pelaksanaan program-program penyuluhan, yang dipilih adalah googlemeet sedangkan untuk komunikasi antara penyuluh (PPL) dan gapoktan atau antara gapoktan dan poktan adalah dengan menggunakan WA grup (WAG).

Teknologi Informasi dan Komunikasi | 50 


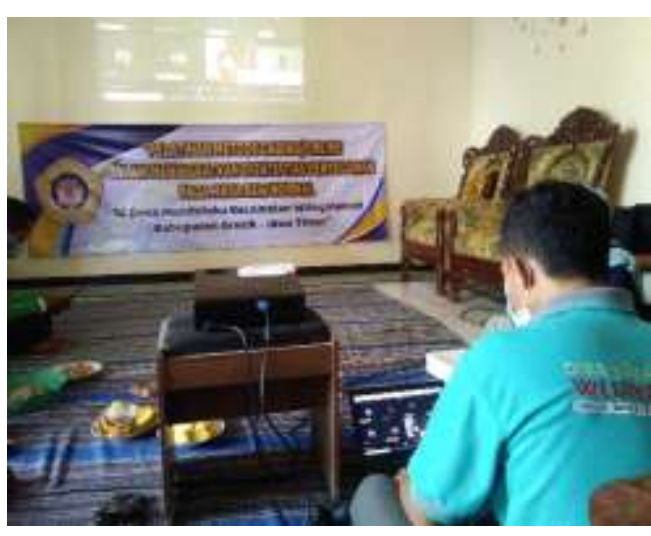

c) Dalam proses praktek penggunaan aplikasi yang telah disepakati yaitu Googlemeet dan WAG, terlihat antusiasme dari peserta, baik dari penyuluh (PPL) maupun perwakilan dari Gapoktan. Dari praktek yang dilaksanakan dapat dinilai bahwa peserta dari pihak penyuluh (PPL) lebih cepat dapat menguasai informasi yang disampaikan, dan terlihat dari kemampuan praktek yang dilakukannya. Disisi lain peserta dari gapoktan yang sedikit memiliki kendala dalam melakukan praktek dalam penggunaan aplikasi, dan ini sangat terlihat dengan banyaknya pertanyaan yang disampaikan adalah peserta dari gapoktan khususnya berkaitan dengan praktek penggunaan aplikasi dengan baik.

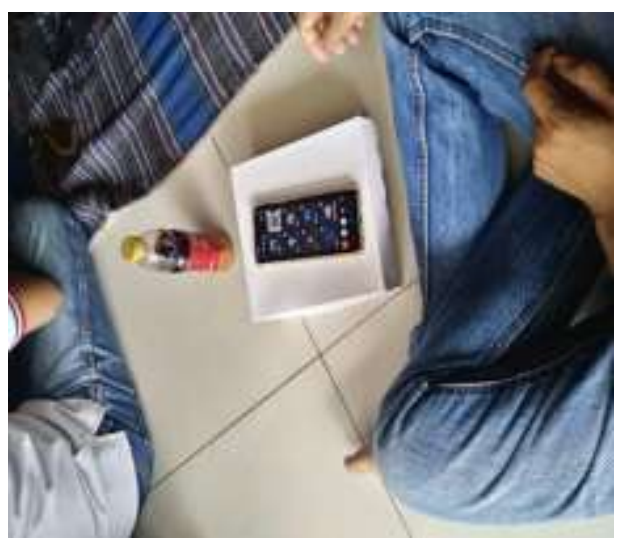

Akan tetapi, secara keseluruhan dapat dinilai bahwa para peserta cukup aktif dan menguasai dalam menggunakan HP berbasis android, akan tetapi hanya digunakan dalam aktivitas sosial, seperti whattshap.

d) Tahap Pendampingan

Selanjutnya tim PPM melakukan pendampingan bagi penyuluh (PPL) dan juga bagi tim gapoktan, pendampingan ini dilakukan untuk mengetahui dan mengevaluasi tentang ketrampilan dan kreatifitas dari penyuluh untuk menyiapkan materi program penyuluhan yang akan digunakan pada aplikasi googlemeet sedangakan pendampingan bagi tim gapoktan adalah untuk mengetahui pemahaman mereka dalam menggunakan googlemeet, baik dalam menerima informasi maupun dalam melakukan komunikasi dengan poktan yang ada dibawah mereka.

Pendampingan yang dilakukan tim PPM dengan meminta bantuan tim penyuluh (PPL) agar dapat mendampingi tim gapoktan sehingga proses pendampingan menjadi lebih intensif dan peserta lebih cepat mampu menggunakan berbagai aplikasi bidang pertanian tersebut.

\section{Tahap Evaluasi}

Setelah kedua tahapan dilaksanakan yaitu; tahap perencanaan dan tahap pelaksanaan, tahap selanjutnya adalah evaluasi. Tahap evaluasi dilaksanakan guna mengetahui keberhasilan kegiatan, tim PPM mengevaluasi perubahan dalam pemahaman dan perilaku. Tahap evaluasi

Teknologi Informasi dan Komunikasi | 51 
dilakukan sebagai kelanjutan dari pendampingan yang dilakukan, hal ini dimaksudkan untuk mengetahui dan mendapatkan infomasi dari tim penyuluh (PPL) maupun tim gapoktan tentang kendala-kendala yang sering terjadi dari pemakaian aplikasi teknologi komunikasi yang telah disepakati dalam pemakaiannya, baik untuk proses pemberian penyuluhan yang bisa dilaksanakan secara daring maupun proses komunikasi antara penyuluh (PPL) dan gapoktan atau sebaliknya.

Guna keberlanjutan program pengabdian kepada masyarakat yang telah dilakukan, tim PKM akan terus melakukan pendampingan dan diskusi secara berkala khususnya kepada PPL berkaitan dengan aplikasi teknologi komunikasi, Karen tim beranggapan bahwa PPL sebagai tim yang mempunyai kewajiban dalam tugasnya untuk menyampaikan serta menyebarluaskan teknologi dan informasi kepada petani guna peningkatan produk dan pengetahuan mereka agar mampu meningkatkan perekonomian keluarga petani.

\section{KESIMPULAN}

Kegiatan pengabdian kepada masyarakat yang dilaksanakan dengan proses pelatihan diharapkan dapat memperluas pengetahuan PPL dan Gapoktan tentang jenis, kegunaan dan manfaat aplikasi yang dapat diperoleh pada handphone yang berbasis android. Selain itu, kegiatan ini juga dapat memberikan motivasi dan peningkatan keterampilan dan kemampuan PPL dan gapoktan dalam penggunaan berbagai aplikasi pertanian berbasis android. Sehingga setelah kegiatan pelatihan ini, PPL dan gapoktan tambahan pengetahuan, ketrampilan serta memahami aplikasi yang ada pada alat komunikasi modern yang bisa memberikan informasi terkini khususnya menerima informasi dari PPL berkaitan dengan perkembangan pada sektor pertanian, lebih tepatnya pengetahuan berbasis kebutuhan, lebih lengkap, modern dan lebih sederhana.

Program kegiatan pengabdian kepada masyarakat berkaitan dengan penggunaan metode daring dalam proses penyuluhan yang telah dilaksanakan melalui beberapa tahapan dapat meningkatkan pengetahuan dan ketrampilan penyuluh (PPL) dan gapoktan tentang jenis, kegunaan dan manfaat berbagai aplikasi teknologi komunikasi yang dapat dimanfaatkan untuk proses penyuluhan dan komunikasi secara masa dan tersedia pada HP yang berbasis android. Sehingga, setelah kegiatan pelatihan ini penyuluh (PPL) dan gapoktan memiliki banyak harapan terkait aplikasi yang ada yaitu dengan memberikan informasi terbaru terhadap perkembangan bidang pertanian, lebih spesifik, pengetahuan sesuai dengan kebutuhan, lebih lengkap lagi, lebih update dan lebih simpel. Selain itu, kegiatan ini juga dapat memotivasi dan meningkatkan ketrampilan dan kompetensi penyuluh (PPL) dan gapoktan dalam menggunakan teknologi komunikasi digital.

\section{UCAPAN TERIMA KASIH}

Ucapan terima kasih tim PPM disampaikan kepada Universitas Wijaya Putra melalui LPPM yang memberikan kepercayaan kepada tim untuk mendanai pelaksanaan pengabdian kepada masyarakat melalui Anggaran Dana LPPM Tahun Akademik 2020/2021 dan Surat Perjanjian Pelaksanaan Program Pemberdayaan Bagi Dosen Universitas Wijaya Putra Masyarakat Nomor :052.071/LPPM-UWP/K-I/V/2021 tanggal 27 Mei 2021.

\section{REFERENSI}

\author{
Andini, Nurulitha., dalam \\ "Pengorganisasian Komunitas Dalam \\ Pengembangan Agrowisata di Desa Wisata \\ Studi Kasus: Desa Wisata Kembangarum, \\ Kabupaten Sleman, Jurnal Perencanaan \\ Wilayah dan Kota, Vol. 24 No. 3, \\ Desember 2013.
}

Teknologi Informasi dan Komunikasi | 52 
Bahua, Mohamad Iqbal. (2016).

Kinerja Penyuluh Pertanian. Yogyakarta: Deepublish.

Hidayati, Permata Ika. (2014).

Penyuluhan dan Komunikasi. Malang:

Universitas KanjuruhanPress.

Kusumasari, Bevaola, dan Hempri Suyatna, dalam "Peningkatan Kapabilitas Pemasaran Pascabencana Bagi Perempuan Hunian Tetap Pager Jurang, Sleman, Yogyakarta", Jurnal Indonesian Journal of Community Engagement Vol. 01. No. 01, September 2015

Nadir, Sakinah., dalam "Otonomi Daerah dan Desentralisasi Desa: Menuju Pemberdayaan Masyarakat Desa, Jurnal Politik Profetik Volume 1 Nomor 1 Tahun 2013

Widjajanti, Kesi, dalam "Model Pemberdayaan Masyarakat", Jurnal Ekonomi Pembangunan Volume 12, Nomor 1, Juni 2011 